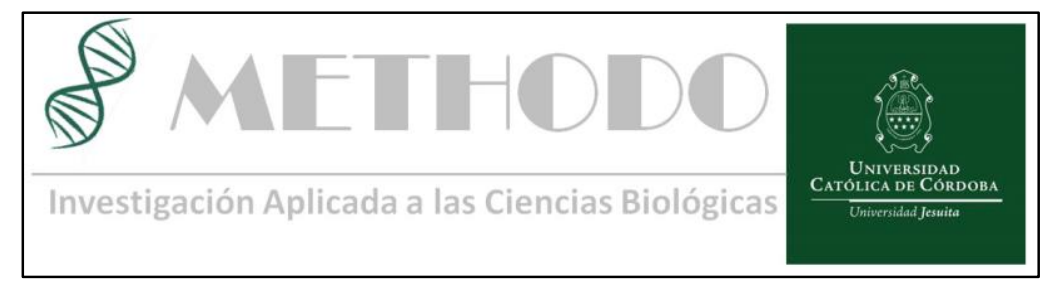

\title{
Condiciones inflamatorias no infecciosas en el contexto de la fiebre de origen desconocido: el ejemplo de enfermedad de Still *
}

\section{Noninfectious inflammatory conditions in the context of fever of unknown origin: the example of adult onset Still's disease *}

*Trabajo Presentado en las XIV Jornadas de Investigación de la Clínica Universitaria Reina FabiolaOctubre de 2017

Córdoba $\mathrm{M}^{1}$, Bertoli A $^{1}$, Gutiérrez Magaldi I², Apaz MT¹, Sánchez Freytes M$^{1}$.

\section{Introducción:}

La lista de etiologías en la fiebre de origen desconocido (FOD) es extensa, siendo las infecciones una causa significativa. Aunque en la actualidad, la mayoría de los casos se deben a desórdenes inflamatorios no infecciosos. La enfermedad de Still del adulto (ESA) es una entidad poco frecuente que sólo debe considerarse luego de descartar otras etiologías. El diagnóstico es clínico ya que no se disponen de métodos complementarios específicos ${ }^{1}$. El curso clínico se divide en 3 patrones: monofásico, con curso de semanas o meses, intermitente, en brotes y articular crónico ${ }^{2}$. Los fármacos antiinflamatorios no esteroideos y los glucocorticoides son útiles en la enfermedad aguda; dado que las recaídas son comunes, la necesidad de terapia inmunosupresora es frecuente ${ }^{3}$.

\section{Desarrollo de los casos}

Se analizaron los datos de ocho casos de pacientes con ESA utilizando los criterios clasificatorios de Yamaguchi ${ }^{4}$. Se registraron las características clínicas, de laboratorio, el curso de la enfermedad y terapéutica utilizada. La edad de inicio varió de 19 a 68 años con una relación hombres/mujeres de 5:3.

La fiebre fue el síntoma de presentación en todos los casos, el rash evanescente se presentó en siete pacientes, la afectación poliarticular en seis y odinofagia en tres. Tres pacientes presentaron derrame pericárdico y pleural, en uno de los cuales se realizó pericardiocentesis y en otra ventana pericárdica debido al compromiso hemodinámico. Un caso se asoció a anemia hemolítica. Las manifestaciones de laboratorio más frecuentes fueron: leucocitosis (rango 10.300-50.000/mm3), trombocitosis (rango 205.000-760.000/mm3), elevación de la eritrosedimentación (rango 80$104 \mathrm{~mm}$ en la primera hora), elevación de transaminasas GOT, GPT y de la ferritina sérica (rango 71-1500 ng/ml).

Cuatro pacientes tuvieron un curso monofásico, tres un curso intermitente y uno presentó compromiso crónico articular. Todos los pacientes recibieron AINE y glucocorticoides con remisión completa sólo en cuatro pacientes. Aquellos con curso intermitente y crónico requirieron terapia inmunomoduladora. Los datos detallados por paciente se muestran en la Tabla 1.

\section{Conclusiones:}

La ESA suele ser un diagnóstico enigmático dentro del listado etiológico de la FOD. La dificultad diagnóstica reside en la gran constelación de síntomas y signos, la ausencia de una prueba específica para el diagnóstico y criterios clasificatorios poco específicos. Dada su baja incidencia, la ESA se constituye, 
además, como un diagnóstico de exclusión. En esta serie de casos, enfatizamos la ESA como causa de FOD en nuestro medio, así como las características demográficas, clínicas y evolutivas consistentes con las publicadas por otros autores.

Tabla 1. Manifestaciones clínicas, de laboratorio y tratamiento en pacientes con enfermedad de Still del adulto.

\begin{tabular}{lccc} 
& \multicolumn{3}{c}{ Genero } \\
Manifestaciones clínicas & Total & Masculino & Femenino \\
Fiebre & 8 & 5 & 3 \\
Rash & 7 & 4 & 3 \\
Artralgias & 6 & 3 & 3 \\
Odinofagia & 3 & 1 & 2 \\
$\quad$ Astenia & 2 & 1 & 1 \\
$\quad$ Derrame pericárdico & 3 & 3 & - \\
$\quad$ Derrame pleural & 3 & 3 & - \\
$\quad$ Anemia hemolítica & 1 & 1 & - \\
Laboratorio & & & \\
Leucocitosis & 8 & 5 & 3 \\
$\quad$ Elevación de Transaminasas & 6 & 4 & 2 \\
$\quad$ Trombocitosis & 4 & 3 & 1 \\
$\quad$ Elevación de VSG-PCR & 7 & 4 & 3 \\
$\quad$ Elevación de ferritina & 5 & 4 & 1 \\
Tratamiento & & & \\
Glucocorticoides & 8 & 5 & 3 \\
$\quad$ Respuesta completa & 4 & 2 & 2 \\
$\quad$ Respuesta parcial & 4 & 3 & 1 \\
Otros tratamientos & & & \\
$\quad$ Metotrexato & 3 & 2 & 1 \\
$\quad$ Hidroxicloroquina & 1 & 0 & 1 \\
$\quad$ Tocilizumab & 1 & 1 & 0
\end{tabular}

\section{Introduction:}

Many conditions may cause fever of unknown origin (FUO). While infections remain a significant cause, most FUOs are caused by noninfectious inflammatory disorders. Adult onset Still's disease (AOSD) is a rare condition that should be considered only after the exclusion of other disorders that can cause FUO. The diagnosis of AOSD remains clinical as other diagnostic markers are not available yet $^{1}$. The disease may present with three different patterns: monophasic, intermittent with relapses and chronic articular ${ }^{2}$. Typically, AOSD is treated with NSAIDs and glucocorticoids, however, relapses are frequent ensuing the use of immunosuppressive drugs ${ }^{3}$.

\section{Results}

Data from eight patients with AOSD were analyzed. The diagnosis was based on the Yamaguchi criteria ${ }^{4}$ after exclusion of infections, hematological and autoimmune diseases.
Clinical and laboratory characteristics, disease course and therapeutic were recorded.

The age of onset varied from 19 to 68 years old with a male / female ratio of 5: 3 .

Fever was the presenting symptom in all patients, evanescent rash was present in seven, polyarticular involvement in six and odynophagia in three. The patients had pericardial and pleural effusion, one of them requering pericardiocentesis and another a pericardial window due to cardiac tamponade. One case also developed hemolytic anemia. The most frequent laboratory findings were leukocytosis (range 10,300-50,000/mm3), thrombocytosis (range 205,000$760,000 / \mathrm{mm} 3$ ), elevation of erythrocyte sedimentation rate (range 80-104 mm during the first hour), elevation of ALT AST and serum ferritin (range 71-1500 ng/ml).

Four patients had a monophasic course, three patients had an intermittent course, and one patient developed a chronic articular involvement. All patients received NSAIDs and glucocorticoids with a complete remission in four patients and partial remission in four. The latter required immunosuppressive therapy with methotrexate (three patients), hydroxychloroquine (one patient) and tocilizumab (one patient). The details of the clinical, laboratory and treatment data are shown in the Table 1.

\section{Conclusions:}

AOSD is regarded as an enigmatic diagnosis within the etiological listing of FOD. The diagnostic difficulty lies on the great constellation of symptoms and signs that may display this entity, the absence of a specific test for the diagnosis and lack of specificity of the classification criteria. Because of its low incidence, AOSD is a diagnosis of exclusion. In this series of cases, we emphasize AOSD as a cause of FUO. We also show the demographic and clinical features, as well as the disease course of our patients with AOSD that are consistent with those published by other authors. 
Córdoba MC, Bertoli A, Gutiérrez Magaldi I, Apaz MT, Sánchez Freytes M. Condiciones inflamatorias no infecciosas en el contexto de la fiebre de origen desconocido: el ejemplo de enfermedad de Still

\section{Bibliografía}

1. Efthimiou P, Paik PK, Bielory L. Diagnosi and management of adult onset Still' disease. Ann Rheum Dis. 200r May;65(5):564-72

2. Mandl. A Clinical manifestations an diagnosis of adult still disease. Up to dat 2016.

3. Singh, R. Samant, V. R. Joshi. Adult onse Still's disease: a study of 14 cases. Cli1 Rheumatol 2008 27:35-39.

4. Yamaguchi, $\mathrm{M}$ et al. Preliminary criteria fo classification of adult Still's disease. Rheumatol. 1992 Mar;19(3):424-30. FERRITIN, ARTHRALGIA

${ }^{1}$ Servicio de Reumatología, ${ }^{2}$ Servicio de clínica Médica. Clínica Universitaria Reina Fabiola, Universidad Católica de Córdoba, Argentina. Correspondencia: María Cecilia Córdoba. Clínica Universitaria Reina Fabiola. Oncativo 1248 -X5004FHP- Córdoba, Argentina. e-mail: cecordoba26@gmail.com 